\title{
Comunicação intercultural em uma empresa transnacional: a visão dos brasileiros sobre sua comunicação com os norte-americanos
}

\author{
Intercultural communication in a transnational company: the Brazilian of view of its \\ communication with North- Americans
}

\author{
Ana Carolina Pimentel Duarte da Fonseca ${ }^{1}$
}

\begin{abstract}
Resumo
Cada vez mais a globalização leva as empresas a se comunicarem com culturas diferentes das suas em operações interdependentes. Desta forma, torna-se importante detectar e analisar questões a serem compreendidas pelas organizações na sua comunicação com outras culturas; mais especificamente, aspectos que podem resultar em uma interpretação equivocada das mensagens enviadas de uma cultura para a outra. Para compreender melhor essa questão, foram analisadas as duas atividades simbólicas destacadas por Porter e Samovar (1995) no processo de comunicação verbal - o uso de linguagem e a atividade interna de pensar - à luz das dimensões culturais propostas por Hofstede (1980), Trompenaars (1995) e Hall (1984). Foi realizada uma pesquisa de campo qualitativa de caráter descritivo por meio de entrevistas semiestruturadas na subsidiária localizada na cidade do Rio de Janeiro de uma empresa transnacional de origem norte-americana que atua no setor de telecomunicações. Durante as entrevistas com o diretor e dois gerentes, foram enfatizados alguns pontos negativos na interação entre as duas culturas, mas também foi apontada a possibilidade de captar sinergias da diversidade cultural, como sugerem os bons resultados do estilo relacional dos brasileiros com os clientes e o efeito motivador, nos brasileiros, do tratamento mais igualitário adotado pelos chefes americanos.
\end{abstract}

Palavras-chave: Comunicação intercultural. Cultura brasileira. Cultura norte-americana. Empresas transnacionais.

\begin{abstract}
:
Globalization forces organizations to communicate with different cultures in their interdependent operations. Thus, it seems important to detect and analyze issues that have to be understood by organizations in their communication with other cultures, more specifically, aspects that can result in an incorrect interpretation of the messages sent from one culture to another. Aiming to understand this subject more deeply, the two symbolic activities pointed out by Porter and Samovar (1995) in the verbal communication process- use of language and internal activity of thinking- were analyzed using the cultural dimensions proposed by Hofstede (1980), Trompenaars (1995) and Hall (1984). A qualitative descriptive field research based on semi structured interviews was carried in the Rio de Janeiro subsidiary of a NorthAmerican transnational organization that works in the telecommunication area. During the interviews with the director and two managers, there were emphasized some negative points in the interaction of the two cultures, but it was also pointed out the possibility of grasping synergies from cultural diversity, as suggested by the good results obtained by the Brazilian relational style in dealing with customers, and the motivating effect caused on Brazilian subordinates by the more egalitarian treatment adopted by their American superiors.
\end{abstract}

Keywords: Intercultural communication. Brazilian culture. North-American culture. Transnational companies

Artigo submetido em 25 de maio de 2011 e aceito para publicação em 01 de julho de 2011.

1 Doutora em Administração pela Universidade Federal do Rio de Janeiro/COPPEAD; Professora Associada I da Universidade Federal do Rio de Janeiro. Endereço: UFRJ/FACC - Faculdade de Administração e Ciências Contábeis, Av. Pasteur, 250, Urca, CEP 22290240, Rio de Janeiro - RJ, Brasil. E-mail: anafonseca@ufri.br 


\section{Introdução}

Cada vez mais a globalização leva as empresas a se espalharem por diversas regiões, buscando aproveitar as localizações ótimas para executarem atividades ao longo de suas cadeias de valor. Em decorrência disso, essas organizações são obrigadas a se comunicar com culturas diferentes das suas em operações interdependentes. Mesmo em empresas multinacionais que, conforme ressaltam Bartlet e Ghoshal (1992), possuem subsidiárias relativamente independentes umas das outras, a comunicação intercultural se faz presente, seja por intermédio dos expatriados que precisam se expressar dentro das subsidiárias em que foram alocados, seja por meio dos locais que necessitam manter contato com a matriz.

Sendo assim, torna-se importante compreender os aspectos envolvidos na comunicação entre diferentes culturas no âmbito das empresas, ressaltando-se a inter-relação de três variáveis: comunicação, cultura e empresas, já que o comportamento de cada uma delas influencia o comportamento das outras duas.

A comunicação verbal, dentro da comunicação intercultural nas organizações, assume especial importância na medida em que é a principal forma utilizada pelas matrizes para comunicar suas políticas às subsidiárias e estimular seu comportamento no sentido do alcance dos objetivos organizacionais; de forma inversa, é mediante a linguagem que as subsidiárias procuram esclarecer suas dúvidas e justificar os desvios em relação às metas fixadas pela matriz.

O presente trabalho, visando contribuir para um melhor entendimento desse tema, procurou detectar e analisar questões importantes de modo a evitar interpretações equivocadas na comunicação verbal entre culturas. Para atingir este objetivo, optou-se pela análise do processo de comunicação dentro da subsidiária brasileira de uma empresa transnacional de origem americana que atua no setor de telecomunicações. Mais especificamente, foram confrontadas as proposições teóricas encontradas na literatura, no que se refere às implicações das diferenças culturais na comunicação dentro do ambiente de negócios, com os resultados encontrados em entrevistas em profundidade realizadas dentro da subsidiária.

Na próxima seção são descritos os principais aspectos envolvidos nos conceitos de comunicação, cultura e negócios. Na terceira seção destacam-se questões específicas da influência da cultura na comunicação verbal dentro do ambiente empresarial, com base em dimensões culturais selecionadas na literatura. Em seguida, na quarta seção, comparando-se a cultura norte-americana com a brasileira, especificam-se as implicações esperadas das diferenças culturais no processo de comunicação verbal entre as duas culturas. Após a descrição da metodologia empregada, a sexta seção apresenta as informações depreendidas das entrevistas, seguidas de sua análise, na qual se buscou comparar os aspectos anteriormente determinados na quarta seção com os resultados encontrados. Como conclusão, ressaltam-se algumas reflexões sobre os resultados encontrados.

\section{A Comunicação Intercultural nos Negócios}

De acordo com Porter e Samovar (1994), a comunicação enfoca o comportamento de um indivíduo (emissor) que causa ou provoca uma resposta em outro indivíduo (receptor); para que a comunicação seja completa, o segundo indivíduo deve atribuir um significado ao comportamento do primeiro. Esse processo de interpretação é realizado com base em sua experiência passada.

O conceito de cultura tem sido relacionado com a ideia de código. De acordo com Rocha (1994, p. 88-89), "Cada um de nós, enquanto ator social, existe e troca mensagens dentro de um código fundamental que temos em comum. Este código é a cultura. [...] Tal como um código, a cultura fala da existência segundo as regras do seu jogo". 
Conforme destaca Barnlund (1994), cada cultura cria um "universo de discurso" para seus membros, uma forma por meio da qual cada pessoa pode interpretar os fatos e transmiti-los aos outros. Esse "universo de discurso" é propagado de geração para geração, tanto consciente como inconscientemente. Assim, por serem transferidos, em grande parte implicitamente, pela sugestão de comportamentos adequados, os preconceitos e suposições neles contidos são difíceis de serem reconhecidos. É, portanto, necessário identificar as regras de significado que distinguem uma cultura da outra.

Adler (1991) aponta três fontes de falhas na interpretação de significados entre culturas distintas: o uso de suposições ou normas de uma cultura para compreender a outra; a falta de conscientização da própria cultura; e a tendência a ver as outras culturas como mais similares à própria cultura do que realmente são. Para superar essas dificuldades, a autora propõe que se assumam diferenças até que se prove que existem semelhanças. Além disso, acredita que, para compreender outras culturas, é importante enfatizar a descrição, observando o que realmente é dito ou feito. Desta forma, retardam-se interpretações ou avaliações até que se obtenham subsídios para fazer julgamentos do ponto de vista da cultura analisada, e não da ótica do observador. Finalmente, sugere que as interpretações a respeito da cultura que se deseja conhecer sejam verificadas e avaliadas constantemente.

A forte relação entre cultura e comunicação é destacada por Hall (apud SCHALL, 1983), para quem cultura e comunicação são sinônimas; ou ainda, por Paranowsky e O'Donnell (apud SCHALL, 1983), que se referem à cultura como um resíduo do processo de comunicação.

Segundo Schall (1983), as pessoas interagem trocando mensagens mediante transações simbólicas que contêm significado, ou seja, comunicando-se. Depois de repetido "uso", os significados que foram negociados inicialmente tornam-se aceitos, até mesmo incorporados. Deste modo, as culturas são criadas, sustentadas, transmitidas e modificadas com a interação social, por meio de modelagem e imitação, instrução, correção, negociação, histórias, fofocas, retificação, confrontação e observação, atividades baseadas na troca de mensagem e atribuição de significados, ou seja, na comunicação.

Em sentido inverso, Porter e Samovar (1994) observam que é pela influência da cultura que as pessoas aprendem a se comunicar. Pessoas de uma mesma cultura comunicam-se entre si porque seu comportamento comunica significado na medida em que é aprendido e compartilhado, ou seja, culturalmente determinado. Assim, as pessoas veem seus mundos por meio de categorias, conceitos e rótulos que são produtos da sua cultura.

A comunicação entre culturas é efetiva se os significados atribuídos pelos receptores estão próximos daqueles planejados pelos emissores, isto é, quando os esquemas mentais que o emissor projeta a respeito da cultura do receptor estão próximos da realidade. Se as prioridades da cultura do emissor condicionam as características que ele procura em outras culturas, pode haver distorções, dificultando a ligação entre códigos e significados (BEAMER, 1995).

Como observam Porter e Samovar (1994), a comunicação não acontece no vácuo e, sim, dentro de um contexto. Varner (2000) argumenta que a comunicação intercultural nos negócios é mais do que a soma das partes: o processo resulta numa nova sinergia entre cultura, comunicação e negócios, que ajuda a criar um novo ambiente, um novo constructo. Nesse esforço, os membros das organizações devem compreender a relação entre negócios e cultura em um ambiente particular. Qual é o status social dos negócios? Qual a influência que a cultura tem nas estruturas organizacionais? O resultado é um sistema complexo constituído de três camadas: cultura, comunicação e negócios. Seria impossível retirar a camada relativa a negócios e substituí-la por outra referente a um contexto distinto, como medicina e religião.

De acordo com Schall (1983), organizações vistas como cultura têm sido consideradas um fenômeno de comunicação, ou seja, entidades desenvolvidas e mantidas apenas por meio de contínua atividade de comunicação, trocas e interpretações entre seus participantes. Sem a comunicação e o ato de se comunicar, não existiriam a organização e o ato de se organizar. Os participantes, ao interagirem, organizam-se por meio 
da atividade de comunicação e desenvolvem entendimentos compartilhados a respeito de questões de interesse comum e, assim, um senso de "nós" coletivo. Dessa forma, os processos de comunicação inerentes ao ato de se organizar criam uma cultura organizacional, revelada pelas atividades de comunicação.

No entanto, as culturas organizacionais também sofrem influência das culturas nacionais, como retratam as diferenças encontradas nos estilos de comunicação e na forma de comunicação com os empregados em empresas multinacionais e transnacionais europeias analisadas por Fourboul e Bournois (1999).

Examinando a interação entre comunicação e culturas nacionais, Boylan (2001) destaca a importância de o emissor se colocar na perspectiva existencial do receptor, vendo (ou dizendo) coisas "do ponto de vista do nativo". Para o autor, dentro das empresas transnacionais, devem ser aceitos os aspectos específicos de cada cultura, encarando-se a diversidade cultural como um recurso em vez de um obstáculo, como uma oportunidade para captar sinergias das diferenças no estilo de trabalho e de comunicação encontrados nas diversas operações espalhadas pelo mundo. Deste modo, aprender a se comunicar por meio de culturas significa aprender a se aculturar, ou seja, aprender a se tornar alguém como o "outro".

Neste sentido, Canclini (2003, p.114-115) aventa a possibilidade de aproximações e convergências entre culturas, tornando-as combináveis sem, no entanto, dissolver as diferenças. Em suas palavras:

Ao relacionar as estratégias globalizadoras e hibridadoras com as diversas experiências de interculturalidade, salta aos olhos que, por mais que se forme um mercado mundial de finanças, de alguns bens e circuitos midiáticos, por mais que o inglês se consolide como 'língua universal', as diferenças persistem, e a traduzibilidade entre as culturas é limitada. Não impossível. Para além das narrativas fáceis da homogeneização absoluta e de resistência local, a globalização nos defronta à possibilidade de apreender fragmentos, nunca a totalidade, de outras culturas e refazer o que imaginávamos como próprio em interações e acordos com outros, nunca com todos.

Assim, em um mundo onde as fronteiras geográficas estão cada vez menos relevantes, cabe destacar a importância de se compreenderem as mudanças em valores culturais de pessoas expostas constantemente a novos ambientes culturais (TARAS, ROWNEY e STEEL, 2009).

\section{A Influência da Cultura na Comunicação Verbal nos Negócios}

A comunicação examinada neste estudo, conforme anteriormente ressaltado, refere-se à comunicação verbal, pois é por meio dela que ocorre a maior parte da comunicação dentro das organizações, principalmente na transmissão de estratégias, objetivos e políticas organizacionais.

Dentro do processo verbal, Porter e Samovar (1995) destacam duas atividades simbólicas intimamente relacionadas: o uso da linguagem verbal e a atividade interna de pensar.

As línguas são sistemas simbólicos desenvolvidos dentro de cada cultura para representar as experiências humanas. Como cada cultura deixa sua marca individual neste sistema, os significados das palavras estão sujeitos a uma variedade de interpretações. Assim, a língua influencia as percepções, transmite significado e ajuda a moldar padrões de pensamento. Conforme explicitado na hipótese de Sapir-Whorf (apud PORTER e SAMOVAR, 1995), a língua é um guia para a realidade social, não sendo apenas um meio de reportar experiências e, sim, uma forma de definir experiência. Os significados são impostos pela língua, que, de acordo com Hoijer (1994), é uma maneira de dirigir as percepções das pessoas e lhes proporcionar formas habituais de analisar a experiência por meio de categorias significativas. Assim, como concluiu Lewis (1996), indivíduos que falam línguas diferentes acabam vendo coisas diferentes. 
Algumas palavras, por serem culturalmente determinadas, não possuem equivalentes diretos em outra língua já que as mesmas experiências não foram vividas pela outra sociedade ou, ainda, porque algumas sociedades não sentem necessidade de expressar determinados conteúdos emocionais ou conceitos específicos. Deste modo, a língua torna-se uma barreira por si só dentro da comunicação entre culturas, sendo os significados muitas vezes alterados nos processos de tradução e versão (PORTER e SAMOVAR, 1995).

Por outro lado, os processos mentais, as formas de raciocinar e de resolver problemas, envolvidos na atividade interna de pensar, também variam entre culturas, afetando a maneira como os indivíduos se comunicam e, portanto, respondem a indivíduos de outra cultura. Liberman (1994) acredita que determinados padrões de pensamento predominam dentro de uma cultura. Como estes padrões têm sido associados a diferentes hemisférios do cérebro, acredita-se que a primeira língua aprendida desenvolva os padrões de pensamento da pessoa e influencie a forma como as duas metades do cérebro irão processar a língua. O hemisfério esquerdo do cérebro tem sido associado a análise sistemática, abstração, relações lineares e atribuições de causa e efeito; o hemisfério direito estaria relacionado com a intuição, a síntese e a captação dos aspectos holísticos e concretos do problema.

\section{Os instrumentos para analisar diferenças culturais}

Em sua revisão a respeito de instrumentos para medir cultura e modelos teóricos subjacentes, Taras, Rowney e Steel (2009) observaram que, com exceção de algumas poucas abordagens qualitativas, a maioria dos modelos que se propõem a medir cultura é representada por um conjunto de dimensões que buscam quantificar valores culturais, atitudes ou práticas. Os autores concluíram que, embora sejam úteis para fazer comparações entre culturas, esses estudos quantitativos frequentemente deixam de captar as especificidades relacionadas a culturas específicas.

Entre os modelos analisados, Taras, Rowney e Steel (2009) destacam a publicação da obra de Hofstede intitulada Culture's Consequences, em 1980, que provocou um súbito aumento no interesse a respeito da mensuração de culturas, sendo notória a influência das dimensões propostas por Hofstede (1980) em estudos subsequentes. Entre os 121 modelos examinados, foram identificados 26 aspectos que puderam ser agrupados, com poucas exceções, em quatro blocos principais relacionados a quatro das cinco dimensões propostas por Hofstede: coletivismo-individualismo, masculinidade-feminilidade, fuga à incerteza e orientação para o tempo.

De acordo com Ulijn et al. (2000), os trabalhos de Hofstede têm sido a melhor representação de como as culturas nacionais influenciam a comunicação nas organizações. Entretanto, corroborando as críticas de Taras, Rowney e Steel (2009), os autores criticam as generalizações exageradas sobre os efeitos culturais na comunicação e a convergência de valores culturais distintos presentes na abordagem das dimensões culturais de Hofstede no estudo da comunicação nas empresas. Assim, os autores indagam quais tipos de medida e conceito devem ser utilizados para entender a comunicação em empresas localizadas em culturas diferentes.

Tendo em vista essas questões, buscou-se um modelo de análise para o presente estudo. Em virtude de sua importância na literatura, optou-se por utilizar o modelo de Hofstede (1980) para compreender a influência das diferenças culturais no processo de comunicação verbal. Entretanto, para evitar generalizações inadequadas, a análise foi complementada com os modelos de Trompenaars (1995) e Hall (1984) escolhidos por abordarem aspectos relacionados ao uso da linguagem e à atividade interna de pensar, ou seja, às atividades simbólicas destacadas por Porter e Samovar (1995) no processo verbal. Cabe destacar que, entretanto, em cada modelo, só foram consideradas as dimensões que se julgou poder causar algum tipo de impacto no processo. Desta forma, foram selecionadas as seguintes dimensões: 
- distância do poder, fuga à incerteza, individualismo versus coletivismo (modelo de Hofstede);

- universalismo versus particularismo, culturas afetivas versus neutras, culturas específicas versus difusas (modelo de Trompenaars);

- culturas de alto contexto versus de baixo contexto; culturas monocrônicas versus policrônicas (modelo de Hall).

A seguir apresentam-se os impactos das dimensões selecionadas no processo verbal.

\section{Impactos possíveis das diferenças culturais na comunicação verbal}

Foram determinados alguns aspectos do processo de comunicação verbal que poderiam estar sujeitos ao impacto das diferenças culturais envolvidas nas dimensões selecionadas. São eles: a quantidade de informação codificada no processo verbal, a maneira de organizar os assuntos no tempo, o conteúdo da informação, o confronto de opiniões, a quantidade de estrutura contida nas informações e a transparência de emoções no discurso.

\section{A quantidade de informação codificada no processo verbal}

Segundo Trompenaars (1995), a sociedade ocidental é predominantemente uma cultura verbal, as pessoas ficam nervosas e desconfortáveis com o silêncio. Este comportamento contrasta com o de outras culturas como a japonesa ou a finlandesa, onde, como observa Lewis (1996), o silêncio não é considerado falha de comunicação, mas parte integrante da interação social. O que não é dito é percebido como importante, os silêncios são considerados reparadores, amigáveis e apropriados, já que significam que o receptor está processando o que foi dito. Falar muito pode significar egoísmo e arrogância.

A quantidade de informação que é codificada na mensagem verbal é determinada pela dimensão cultural relacionada ao contexto. Nas transações de alto contexto, grande parte da informação está implícita; muito pouca informação é codificada na mensagem verbal, e como se acredita que exista informação suficiente disponível no ambiente, considera-se desnecessário afirmar verbalmente o que parece óbvio. A comunicação de alto contexto é econômica, rápida, eficiente e satisfatória. No entanto, é necessário despender tempo em programação, ou seja, na conscientização do receptor a respeito do contexto. Ela age como uma força unificadora e difícil de mudar, proporcionando estabilidade. Em transações de baixo contexto, a maior parte da informação deve estar na mensagem verbal, de forma a compensar o que não se depreende do contexto. As comunicações de baixo contexto não unificam, mas podem ser rápida e facilmente modificadas, permitindo adaptabilidade (HALL, 1994a).

Haworth e Savage (1989), com base nos conceitos de Hall, propuseram um modelo que torna explícito o montante de conhecimento comum entre o emissor e o receptor, bem como a quantidade de informação explícita em relação à implícita que o emissor envia ao receptor. Se esta taxa for maior do que a requerida, a comunicação se torna mais explícita do que o receptor requer, podendo irritá-lo ou levá-lo a uma interpretação equivocada da mensagem (inferir que as intenções do emissor são outras). Se a taxa for menor, o receptor demandará mais informação do emissor, pois a considerará insuficiente para tomar decisões. $\mathrm{O}$ modelo sugere que o resultado de um desajuste entre a taxa de informação requerida e a explícita será uma comunicação insatisfatória. Os autores ressaltam, entretanto, que em situações pouco familiares as pessoas de culturas de alto contexto podem requerer mais informação explícita e se apoiar menos no contexto do que as pessoas de uma cultura de baixo contexto na mesma situação. 
A dimensão universalismo versus particularismo, proposta por Trompenaars (1995), parece estar relacionada a uma maior ou menor extração de informações do contexto. Nas culturas universalistas são elaborados códigos pré-definidos ou padronizados que servem para todos, de modo que haja equidade entre seus membros. O comportamento universalista tende a ser abstrato, na medida em que ignora as particularidades do contexto ao estabelecer leis universais para os fenômenos. Já nas culturas particularistas, o julgamento depende da relação entre os atores envolvidos numa determinada situação. Quanto mais estreita for a relação entre eles, maior a tendência de que esta não siga a regra formal.

Entre os estilos cognitivos apresentados por Liberman (1994), cabe destacar o da dependência/independência de campo, que pode ser associado à percepção do contexto. O estilo cognitivo de dependência do campo é empregado por culturas mais sensíveis ao ambiente social e tende a considerar as variáveis presentes no ambiente. Sua percepção dos eventos é holística, incluindo a emoção e os sentimentos associados a eles. Existe uma inclinação para a resolução dos problemas em grupo, levando em conta a opinião e os sentimentos das outras pessoas. Já o estilo cognitivo de independência do campo é predominante em sociedades competitivas, altamente industrializadas e de baixo contexto, consistindo em isolar determinadas informações do ambiente e colocá-las em uma relação linear de causa e efeito; enfatiza a lógica do problema, abstraindo-se das emoções do contexto.

\section{A maneira de organizar os assuntos no tempo}

Hall (1994b) relaciona duas formas por meio das quais as sociedades organizam o tempo. No tempo monocrônico, os eventos são agendados separadamente, uma coisa é feita de cada vez; enquanto que no tempo policrônico várias coisas são feitas ao mesmo tempo. Para Hall, o tempo monocrônico reduz o contexto, podendo isolar as pessoas dos outros e de si mesmas. Esta forma de organizar o tempo implica uma maneira de pensar e perceber o mundo em compartimentos estanques. As organizações valorizam as tarefas, cronogramas e procedimentos, e cada assunto é tratado de uma vez. Assim, os membros das organizações monocrônicas, em comparação com os de organizações policrônicas, têm mais dificuldade em pensar suas atividades como parte de um todo maior, já que os últimos estão sempre envolvidos com outras pessoas, fazendo disso a essência de sua existência. As organizações policrônicas apresentam uma estrutura centralizada, na qual o líder fica em contato com muita gente, e vários assuntos são tratados ao mesmo tempo, sobrecarregando a cúpula e tornando as organizações lentas, especialmente quando lidam com qualquer coisa que seja nova ou diferente.

A fraqueza das organizações policrônicas reside na extrema dependência com relação à resolução de problemas por parte do líder; já as organizações monocrônicas tendem a ignorar os aspectos humanos, na medida em que isolam as pessoas e priorizam as tarefas em detrimento das mesmas.

Em geral, no processo de comunicação verbal, nas culturas monocrônicas, as pessoas se sentem desconfortáveis e atordoadas com a maneira como os membros das culturas policrônicas lidam com as situações (sem respeitar a agenda); enquanto que os últimos ressentem-se da pouca importância dada às pessoas (priorizando a agenda) por indivíduos que pertencem a culturas monocrônicas.

As formas de organizar eventos no tempo parecem estar relacionadas às estruturas de discursos utilizadas em diferentes culturas. O estudo de Kaplan (apud ULIJN et al., 2000) mostraram que a estrutura de discursos em inglês variava de acordo com a cultura que a utilizava: circulares, em culturas orientais; lineares, em culturas anglo-germânicas; e digressivas, nas culturas latinas. Da mesma forma, comparando cartas de reclamação escritas em inglês por coreanos e americanos, Park, Dillon e Mitchel (apud ULIJN et al., 2000) verificaram que os coreanos utilizavam um modelo de discurso menos direto e custavam mais a entrar no ponto principal do que seus pares americanos. 


\section{O conteúdo da informação}

Segundo Liberman (1994), as culturas que encorajam a comunicação de baixo contexto são individualistas, enquanto as culturas coletivistas estimulam a comunicação de alto contexto.

Conforme observa Hofstede (1994), nas culturas coletivistas, as pessoas, a partir de seu nascimento, estão integradas em grupos fortemente coesos, que, durante toda a sua vida, continuam a protegê-las em troca de lealdade inquestionável. Existe uma distinção clara entre o "nosso grupo" e o "grupo do outro"; é natural e ético tratar melhor os amigos do que os outros, sendo esta uma sólida prática de negócios. Em consequência deste pensamento, uma relação de confiança deve ser estabelecida com alguém antes que um negócio possa ser fechado, já que as relações pessoais prevalecem sobre a tarefa.

Nas sociedades individualistas, os laços entre indivíduos são frouxos, espera-se que cada um tome conta de si e de sua família imediata. A norma é que todos devam ser tratados igualmente, sendo o tratamento preferencial para um cliente considerado pouco ético e uma má prática de negócios. Supõe-se, ainda, que a tarefa prevaleça sobre quaisquer relações pessoais.

Trompenaars (1995) explica que essas diferentes estratégias de relacionamento vão ter implicações no conteúdo das mensagens transmitidas no processo de comunicação, na medida em que resultam em culturas específicas ou difusas.

Nas culturas específicas, acredita-se que existam tempos, lugares e espaços específicos para as pessoas serem racionais, e tempos, lugares e espaços para serem afetivas. Nessas culturas, a área pública é muito maior do que a privada, e encontra-se dividida em muitas seções específicas, assim, quando alguém é admitido numa seção não significa que o tenha sido nas outras. São culturas individualistas e de baixo contexto, nas quais se vai do específico para o geral, se olha para objetos e coisas antes de verificar como eles se relacionam. Nelas, julga-se suficiente o estabelecimento de regras claras para a condução dos negócios, dispensando um conhecimento mais profundo das pessoas com quem se está fazendo negócios (TROMPENAARS, 1995).

Nas culturas difusas, o espaço privado é bem maior do que o público. No momento em que alguém tenha sido admitido num espaço privado, será aceito em todos, ou quase todos. Tudo está relacionado. As pessoas de uma cultura difusa não conseguem separar suas ideias de si mesmas, os problemas de trabalho dos de casa, ou a pessoa do profissional. Recusam-se a fazer negócios numa subdivisão mental chamada "negócio" ou "trabalho", que é mantida, nas culturas específicas, isolada do resto da vida. São culturas coletivistas e de alto contexto, em que se vai do geral para o específico, se olha para relações e conexões, antes de considerar as partes separadas (TROMPENAARS, 1995).

\section{O confronto de opiniões}

Nas sociedades coletivistas, as opiniões das pessoas têm como base as convicções do grupo, o que dificulta a exposição em público de ideias diferentes daquelas que o líder apresenta. Além disso, a manutenção da "harmonia" é uma preocupação que se estende por todo o ambiente social. A confrontação direta com outra pessoa é considerada rude e indesejável. A palavra "não" é raramente usada, porque dizer "não" significa confronto, assim, "você pode estar certo" ou "vamos pensar a respeito" são maneiras educadas de recusar um pedido. Da mesma forma, a palavra "sim" não significa necessariamente aprovação, mas uma forma de manter a comunicação. Em decorrência disso, no ambiente de trabalho, discutir a performance de alguém pode colidir com a norma social da harmonia e ser encarado pelo subordinado como uma "perda da face" inaceitável, ou seja, um sentimento de vergonha por não agir de acordo com o que era esperado pelo grupo. Essas sociedades têm meios sutis, indiretos de comunicar feedback, como por meio da retirada de um favor ou por um intermediário (HOFSTEDE, 1994). 
Em culturas individualistas, falar o que vem à cabeça é uma virtude, dizer a verdade a respeito de como alguém se sente é uma característica de uma pessoa sincera e honesta e confrontação pode ser salutar; acredita-se que um conflito de ideias leve a uma verdade maior, esperando-se que as pessoas desenvolvam opiniões próprias. Indivíduos adultos devem aprender a ouvir feedback direto construtivamente. Os pacotes de treinamento desenvolvidos nesses países consideram habilidades importantes, em um gerente bem sucedido, a condução da avaliação de performance e saber transmitir "más notícias" (HOFSTEDE, 1994).

Trompenaars (1995) acredita que, nas culturas específicas, se veem coisas impessoais onde nas culturas difusas se veem coisas altamente pessoais. Nesse caso, quando alguma coisa que se percebe como privada torna-se pública, pode ocorrer a "perda da face". A importância de evitar a "perda da face" é a razão da longa demora, nas culturas difusas, para se atingir o ponto, o assunto central. É importante evitar confrontação porque, para os participantes, é impossível não levar as coisas para o lado pessoal.

A forma como os membros de uma sociedade aceitam a desigualdade na distribuição do poder também pode impactar a discussão de ideias entre chefes e subordinados. Segundo Hofstede (1994), nos países em que as pessoas se consideram existencialmente desiguais (grande distância do poder), as organizações centralizam poder em poucas mãos. O modelo vigente é de dependência com relação aos mais velhos, a quem se deve obediência e respeito. Cabe aos superiores na escala hierárquica indicar os caminhos a serem seguidos, bem como iniciar o processo de comunicação. Deste modo, os subordinados esperam que aqueles lhes digam o que deve ser feito, sendo os contatos entre superiores e subordinados iniciados apenas pelos superiores. Existe pouca probabilidade de que os subordinados se aproximem ou contradigam seus patrões.

Nas sociedades com pequena distância do poder, as organizações são bastante descentralizadas, com pirâmides hierárquicas achatadas e limitado número de supervisores. Existe uma pequena distância emocional entre subordinados e patrões, havendo preferência por consultas e interdependência. Os superiores devem ser acessíveis aos subordinados. As intervenções são livres no processo de comunicação, bem como as críticas a superiores hierárquicos aprovadas socialmente. As pessoas são premiadas pela iniciativa, buscando o seu próprio caminho intelectual (HOFSTEDE, 1994).

\section{A quantidade de estrutura contida nas informações}

Como destaca Hofstede (1994), em culturas com forte fuga à incerteza, evitam-se situações ambíguas. As pessoas procuram estrutura em suas organizações, instituições e relações, o que torna eventos claramente interpretáveis e previsíveis: gostam de objetivos precisos, de situações em que existe apenas uma resposta correta e de chefes que saibam todas as respostas. Há muitas regras e regulamentos internos controlando o processo de trabalho, e os funcionários devem ter instruções precisas de seus cargos e tarefas. Os gerentes de topo se preocupam mais com problemas operacionais do que com problemas estratégicos. Assim, são bastante eficazes em implementações que demandam pontualidade e precisão.

Nas culturas com fraca fuga à incerteza, comportamentos desviantes não são necessariamente considerados ameaçadores. As pessoas desprezam muita estrutura e gostam de objetivos vagos e atribuições ou tarefas genéricas. A sugestão de que possa haver apenas uma resposta correta não é bem aceita. Admite-se que chefes assumam quando não sabem alguma coisa. Os gerentes de topo se preocupam mais com problemas estratégicos, os quais, por não serem estruturados por definição, demandam uma maior tolerância por ambiguidade do que os problemas operacionais. Nessas culturas existe maior probabilidade de se estimularem inovações e a criatividade (HOFSTEDE, 1994). 


\section{A transparência de emoções no discurso}

As culturas com maior nível de ansiedade (forte fuga à incerteza) tendem a ser culturas mais expressivas. As pessoas falam com as mãos, sendo socialmente aceitável elevar o tom de voz, mostrar a emoção, bater na mesa. Nas culturas com fraca fuga à incerteza, agressividade e emoções não devem ser expostas; comportamentos barulhentos ou que demonstrem emoção não são aprovados socialmente (HOFSTEDE, 1994).

Trompenaars (1995) denomina neutras as culturas nas quais os sentimentos são controlados, e afetivas aquelas em que as emoções são demonstradas. Segundo o autor, estas diferenças podem ser sentidas na escolha pelo discurso indireto ou direto. Na abordagem neutra, procura-se fundamentar as decisões de forma racional mediante um discurso indireto decorrente de um esforço intelectual. Quando a abordagem é afetiva, busca-se um discurso direto, em que os sentimentos são expostos. Nessas culturas, quando existe uma identificação emocional com uma questão, um julgamento racional pode ser menos importante do que os sentimentos envolvidos.

Para algumas culturas neutras, variações (subidas e descidas do tom de voz) no tom do discurso sugerem que o interlocutor não é sério, enquanto que, em culturas afetivas, significam que a pessoa está envolvida sentimentalmente com o assunto ou que o assunto é importante. Além disso, interrupções do interlocutor, juntamente com o emprego de diminutivos e tentativas de fazer humor estariam presentes nos discursos proferidos nestas últimas sociedades (TROMPENAARS, 1995).

\section{Comparação entre a Cultura Norte-Americana e a Cultura Brasileira}

Nesta seção, além dos modelos usados na anterior, foram abordados autores que escreveram especificamente sobre a cultura norte-americana ou sobre a cultura brasileira, com o intuito de captar as particularidades de cada uma delas contornando generalizações excessivas ou, ainda, associar determinadas especificidades a dimensões mais amplas. Adicionalmente, cabe ressaltar que, ainda que se fale em cultura brasileira ou norteamericana, admite-se que existam variações dentro da cultura de cada um dos países, como constata Tanure (2005) em relação à cultura brasileira. Assim, em seguida, com base na caracterização das duas culturas, foram identificadas algumas possíveis diferenças no processo de comunicação verbal decorrentes das diferenças encontradas.

\section{A quantidade de informação codificada no processo verbal}

Hall (1984) classifica os Estados Unidos como uma cultura de baixo contexto que tem a lógica como única forma de apresentar ideias e a atribuição de números como a única maneira de avaliar performance. De acordo com Hampden-Turner e Trompenaars (1995), entre os países por eles estudados, os EUA se destacam como o mais universalista. Nenhuma outra cultura é tão eficiente em elaborar regras para as pessoas seguirem. O universalismo pode ser observado na tendência de os americanos fazerem simplificações da realidade estabelecendo códigos pré-definidos ou padronizados. Espelha esta característica a própria determinação dos Estados Unidos em proclamar a "supremacia" da Administração de Empresas, estabelecendo para si a tarefa de fazer uma ciência da administração e produzindo uma grande quantidade de técnicas e fórmulas com o objetivo de construir um código de administração universal.

Em contraste, a cultura brasileira é de alto contexto, não sendo explícita e, portanto, interpretada com base em um conjunto de pistas (SOBRAL, CARVALHAL e ALMEIDA, 2007). 
DaMatta (2000, p. 24) explica que na sociedade brasileira existem dois códigos sociais "o código da casa (fundado na família, na lealdade, na pessoa e no compadrio) e o código da rua (baseado em leis universais, numa burocracia antiga e profundamente ancorada entre nós, e num formalismo jurídico legal que chega às raias do absurdo)". Entretanto, para o autor, o que possibilita uma compreensão da sociedade brasileira é o estudo da conexão entre esses elementos. Exemplificando essa inter-relação, Prates e Barros (1997. p. 63) chamam a atenção para a existência, na sociedade brasileira, de uma "aceitação tácita das normas e regras, mas com uma prática distorcida". Para Barbosa (1992, p. 32), o jeitinho brasileiro é "sempre uma forma 'especial' de resolver algum problema ou situação difícil ou proibida; ou uma solução criativa para alguma emergência, seja sob a forma de burla a alguma regra ou norma preestabelecida, seja sob a forma de conciliação, esperteza ou habilidade".

Desta forma, percebe-se que a cultura brasileira, em contraste com a orientação universalista norteamericana, parece ser capaz de lidar com a ambiguidade, captando conexões particularistas. Assim, é provável que os norte-americanos, por extraírem menos informações do contexto, coloquem maior quantidade de informação na mensagem verbal do que os brasileiros. Para os brasileiros, a quantidade de informação explícita enviada pelos norte-americanos seria maior do que a requerida, podendo irritá-los ou levá-los a uma interpretação equivocada da mensagem. Isso só não ocorreria em situações pouco familiares, quando os brasileiros poderiam requerer mais informação explícita que os americanos, conforme sugerem Haworth e Savage (1989).

\section{A maneira de organizar os assuntos no tempo}

Hall (1984) classifica os Estados Unidos como uma cultura monocrônica, na qual existe uma tendência a seguir uma agenda, a compartimentalizar. Seus membros sentem-se psicologicamente perturbados em ambientes policrônicos, nos quais os eventos não obedecem a uma ordem pré-determinada, seja por meio de um número ou de uma fila, ou onde os compromissos futuros possam ser facilmente alterados.

Hampde-Turner e Trompenaars (1995), corroborando a análise de Hall (1984), destacam que os Estados Unidos são essencialmente analíticos e gastam mais energia "desconstruindo" do que construindo, ou seja, enfatizando as partes em detrimento do todo. Os autores chamam a atenção para o risco de uma cultura desse tipo despedaçar-se: estatísticas sem significado, estoques sem finalidade, tarefas sem integração, funções sem coordenação.

Além disso, a necessidade de justificar decisões por números e o processo de raciocínio lógico, decorrentes da visão sequencial do tempo, resultam na percepção de que quanto mais diretas as conexões de causa e efeito, mais robusto o raciocínio (HAMPDEN-TURNER e TROMPENAARS, 1995).

Já na cultura brasileira, parece predominar um tempo policrônico, em virtude de sua tendência a enfatizar as pessoas e o todo em detrimento das tarefas e das partes, conforme sugere a análise de Damatta (2000, p. 25, grifo do autor), para quem:

O ponto é utilizar consistentemente a descoberta de que a sociedade brasileira é relacional. Um sistema onde o básico, o valor fundamental, é relacionar, juntar, confundir, conciliar. Ficar no meio, descobrir a mediação e estabelecer a gradação, incluir (jamais excluir). Sintetizar modelos e posições parece constituir um aspecto central da ideologia dominante brasileira.

Assim, em razão das diferentes concepções do tempo descritas nas duas culturas, é provável que, no processo de comunicação verbal, os norte-americanos sintam-se desconfortáveis e atordoados com a maneira como os brasileiros desrespeitam a agenda. Em contrapartida, a prioridade dada à agenda em detrimento das pessoas 
pode desagradar aos brasileiros. Da mesma forma, essas observações também sugerem que haja uma preferência por parte dos norte-americanos por uma estrutura de discurso linear, que contrastaria com uma estrutura digressiva, característica da cultura brasileira, como constatado por Kaplan (apud ULIJN et al., 2000).

\section{O conteúdo da informação}

Coerentemente com a afirmação de Liberman (1994) de que as culturas que encorajam a comunicação de baixo contexto são individualistas, a cultura norte-americana é apontada como a cultura mais individualista na pesquisa de Hofstede (1994).

De acordo com Trompenaars (1995), o individualismo norte-americano reflete-se no fato de sua cultura exibir um espaço público muito maior do que o privado, sendo este espaço público segmentado em várias seções específicas. Quem penetra em algum desses espaços não deve se sentir íntimo, pois não significa que conseguirá penetrar nos demais. Desta forma, por saberem separar seu espaço privado do público, característica de uma cultura específica, os norte-americanos aceitam o discurso direto, sem levar para o lado pessoal eventuais críticas.

Em pesquisa sobre a diversidade de discursos no ambiente empresarial, comparando a construção de imagem de brasileiros e estrangeiros, Barbosa e Veloso (2009, p. 94) destacam que "quando, ao longo das entrevistas, se perguntava aos brasileiros qual a maior dificuldade que eles encontraram no trabalho e no convívio com pessoas de outra cultura, a frieza, a impessoalidade e a distância das relações pessoais apareciam em primeiro lugar, quando se tratava dos europeus, japoneses e norte-americanos".

Assim, a cultura brasileira, relacional e difusa, destoa da norte-americana, individualista e específica. Desta forma, espera-se que os brasileiros tenham dificuldade de separar o trabalho da vida pessoal, ao contrário dos norte-americanos, que dispensariam um conhecimento mais profundo das pessoas com quem estivessem trabalhando ou fazendo negócios.

\section{O confronto de opiniões}

De acordo com Yeganeh (2011), os americanos apreciam autonomia e a expressão de suas ideias e opiniões, apresentam um estilo direto e explícito, condizente com um estilo de comunicação de baixo contexto.

Como decorrência do individualismo norte-americano, Adler e Jelinek (1986) ressaltam que os americanos acreditam que os indivíduos são capazes de criar e selecionar seus próprios valores, atitudes, comportamentos e direções no mundo. A ideia de não estar condicionado a nenhum tipo de determinismo, seja ele físico, psicológico ou cultural, ou seja, de exercer o livre arbítrio, é, para as autoras, uma característica básica da cultura norte-americana. Assim, a crença no livre arbítrio parece estar relacionada ao debate de ideias e à defesa de opiniões.

No mesmo sentido, Iribarne (2009) aponta que as sociedades se distinguem por um medo fundamental, um perigo temido por todos. No caso da sociedade norte-americana, este medo seria o de estar à mercê das ações de outrem, de não comandar o próprio destino.

Hampden-Turner e Trompenaars (1995) apontam duas características que refletem a crença no livre arbítrio: a ênfase no desempenho como forma de alcançar status (status alcançado) e o tratamento igualitário para 
com os empregados (igualdade), que, por sua vez, corroboram o baixo índice de distância do poder apresentado pelos Estados Unidos no estudo de Hofstede (1980).

Enquanto nos EUA o sujeito do sistema é o indivíduo, no Brasil é também a "relação, o elo, o ponto de ligação", o que permite que, ao contrário dos EUA, haja "junção e hierarquização" onde "há exclusão e separação" (DAMATTA, 2000, p. 108). Estes traços apontam para uma sociedade hierárquica, na qual as relações pessoais são muito importantes, cuja origem remonta, segundo Motta (1997, p. 31), ao "binômio casa grande e senzala", onde "a distância social era contrapartida da proximidade física".

Em razão dessas características, diferentemente da cultura norte-americana, na qual os indivíduos expõem livremente seus pontos de vista, busca-se evitar o conflito de ideias para preservar a harmonia, principalmente no sentido liderado-líder, conforme apontado por Tanure (2005). Corroborando essas conclusões, Hilal e Hofstede (2003) destacam que, em geral, a cultura brasileira é considerada flexível e adaptável e, aparentemente, menos voltada para os extremos, favorecendo, assim, soluções que destacam a harmonia em vez do conflito aberto.

Do exposto, é provável que as atitudes de brasileiros e norte-americanos sejam distintas em relação a conflitos. Enquanto os norte-americanos exporiam livremente seus pontos de vista, os brasileiros tenderiam a seguir a opinião do grupo, preocupando-se em manter a harmonia. Esta tendência se acentuaria na medida em que a discussão de ideias também seria influenciada pelas diferentes formas como as duas culturas aceitam a desigualdade na distribuição do poder. Por ser menos hierárquica e meritocrática do que a brasileira, a cultura norte-americana favoreceria intervenções livres e críticas aos superiores, ao passo que na brasileira existiria pouca possibilidade de os subordinados contradizerem seus patrões ou, até mesmo, iniciarem o processo de comunicação.

\section{A quantidade de estrutura contida nas informações}

As observações de que a cultura norte-americana teria uma forte tendência a estabelecer leis universais parecem contradizer o resultado do estudo de Hofstede (1980), no qual os Estados Unidos obtiveram um índice de fuga à incerteza relativamente pequeno, o que resultaria em uma menor necessidade de estruturação das atividades.

No entanto, embora a cultura brasileira tenha obtido um índice de fuga à incerteza alto no estudo de Hofstede (1980), pesquisas posteriores realizadas por Tanure (2005) indicam que houve uma queda acentuada neste índice. A mudança, atribuída pela autora a décadas de convivência com situações de incerteza, implicaria uma menor necessidade de regras, o que seria consistente com as características de culturas particularistas.

Assim, no que diz respeito à quantidade de estrutura contida nas informações, a comparação entre brasileiros e norte-americanos não parece clara. Por um lado, em virtude da tendência universalista da cultura norteamericana, é possível que haja, de sua parte, uma simplificação das regras e procedimentos para tratar com situações particulares que desagradem aos brasileiros. Por outro lado, como os índices de fuga à incerteza das duas culturas tornaram-se mais próximos, é provável que os brasileiros se sintam confortáveis com o grau de estruturação de tarefas existente.

\section{A transparência de emoções no discurso}

Embora tendam a exibir emoções, os norte-americanos conseguem separá-las das decisões "objetivas" e "racionais" contidas nas relações de negócios (TROMPENAARS, 1995). 
Já os brasileiros parecem ter "horror às distâncias e um desejo contínuo de estabelecer um mínimo de intimidade", buscando relacionamentos "próximos e afetuosos", mesmo "nas relações que deveriam supostamente ser repletas de rigores e formalismos". Essa característica dominou inclusive a linguagem: "o emprego frequente da terminação 'inho' serve também" para que eles familiarizem "com as pessoas ou objetos, para fazê-los mais acessíveis aos sentidos e aproximá-los do coração" (FREITAS, 1997, p. 48-49).

Assim, ao contrário dos norte-americanos, que conseguiriam separar as emoções das decisões "objetivas" e "racionais" contidas nas relações de negócios, por meio de um discurso indireto, os brasileiros continuariam expondo seus sentimentos mediante um discurso direto. Desta forma, é provável que os brasileiros se ressintam da falta de emoção presente no discurso dos norte-americanos, interpretando-a como indiferença, enquanto a presença de emoção no discurso dos brasileiros é encarada como falta de profissionalismo pelos norte-americanos.

\section{A Metodologia Empregada}

\section{O Método}

Para examinar o processo de comunicação intercultural dentro de uma empresa transnacional americana, optou-se pelo método de pesquisa descritivo-qualitativo, com base em entrevistas semiestruturadas realizadas dentro de sua subsidiária brasileira. As perguntas tiveram por base os possíveis impactos das diferenças culturais examinadas nas dimensões propostas por Hofstede (1980), Hall (1984) e Trompenaars (1995) no processo da comunicação verbal.

$\mathrm{O}$ uso de entrevistas semiestruturadas procurou atender a dois objetivos: apreender os significados simbólicos presentes no processo de comunicação intercultural e proporcionar alguma dose de orientação aos informantes, de modo a analisar as questões levantadas na discussão teórica. Assim, ao mesmo tempo que se procurou seguir um roteiro de perguntas, permitiu-se que os entrevistados divagassem com liberdade sobre as questões que julgassem mais importantes.

Segundo Porter e Samovar (1994), é com base nos processos perceptivos na comunicação intercultural que os estímulos do ambiente são selecionados, avaliados e organizados. O conteúdo de uma mensagem pode ser alterado quando decodificado pelo receptor na medida em que este possua repertórios da realidade social, formas de comunicação e sistemas de significados culturalmente diferentes daqueles possuídos pelo emissor da mensagem. Desse modo, como a pesquisa buscou captar percepções culturalmente determinadas, houve a preocupação de coletar informações na perspectiva daqueles que estavam sendo investigados, conforme a metodologia empregada nos estudos etnográficos realizados em Antropologia, por meio da qual se busca decifrar códigos culturais "do ponto de vista dos nativos", conforme sugerido por Adler (1991) e Boylan (2001).

O roteiro básico de entrevistas consistiu de 39 perguntas, das quais sete introdutórias, visando compreender a função do informante e suas inter-relações na empresa, e 32 a respeito dos tópicos analisados na revisão de literatura. Os informantes responderam a todas as perguntas, detendo-se nos pontos que julgavam de maior interesse, apesar da agenda apertada de que dispunham.

\section{A empresa e os informantes}

A empresa estudada, que pediu para não ser identificada, é transnacional norte-americana e atua no setor de telecomunicações. 
A subsidiária, localizada na cidade do Rio de Janeiro, comporta 21 pessoas, todas brasileiras; dez funcionários sem cargo de gerência, dez gerentes e um diretor. Não existem expatriados no escritório estudado.

Dentro da empresa, optou-se por entrevistar pessoas com maior contato com a matriz, o que acabou determinando a seleção de pessoas que pudessem fornecer uma visão mais abrangente, tanto do nível estratégico (diretoria) quanto do nível tático (gerência). Cabe ressaltar que o número de entrevistas realizadas teve relação com a disponibilidade de tempo por parte dos informantes, o que acabou resultando em três entrevistas, sendo uma com o diretor da área e duas com gerentes.

Os informantes tinham entre 35 e 45 anos e haviam ingressado na empresa há, pelo menos, mais de dois anos. Primeiro, foi entrevistado o gerente de suporte técnico e manutenção de serviços vendidos, que trabalha com o pessoal sediado na Argentina. Em seguida, entrevistou-se o diretor da área de vendas e suporte de vendas, cuja responsabilidade se estende pelo Brasil e alguns países da América do Sul. Nessa área, também foi realizada uma entrevista com o gerente do Rio de Janeiro.

As duas áreas estudadas são encarregadas do atendimento a clientes americanos localizados no Brasil. Além de lidarem a maior parte do tempo com norte-americanos, os informantes também interagem com os escritórios da América do Sul e México, entretanto, o foco do estudo foi na comunicação entre brasileiros e americanos, levando-se em consideração a ótica dos brasileiros.

\section{Os resultados das entrevistas}

De uma maneira geral, evidenciou-se a dificuldade que os americanos têm em lidar com outras culturas, seja tentando aplicar cegamente, na subsidiária, tudo o que empregam nos Estados Unidos, seja não reconhecendo, em sua maioria, as diferenças de língua.

O fato de existir uma cultura organizacional forte e bem definida parece facilitar a comunicação. Os informantes demonstraram conhecer exatamente o que se espera deles, afirmando entender como os americanos "funcionam", quais são as "regras do jogo", "o que o cara americano vai gostar". Ressaltam, no entanto, que a regra vem de fora e que os americanos não entendem, nem querem entender como eles "funcionam".

A barreira da língua foi considerada bastante significativa no processo de comunicação. Muitas vezes os brasileiros não conseguem expressar com fluência o que estão pensando, pois nem sempre é possível pensar em inglês, havendo necessidade de "adaptar para o inglês o que querem dizer em português". A dificuldade é ainda maior porque os americanos não reconhecem a diferença de língua, falam bem rápido, fazem uso de gírias, discutindo normalmente, como se a língua fosse a mesma.

De acordo com os informantes, impera na empresa um estilo americano de se comunicar, caracterizado por muitos conference calls e muitas reuniões. O conference call é uma audioconferência, ou seja, uma técnica de comunicação em que várias pessoas estão conectadas na rede telefônica e devem estar preparadas para responder a perguntas e fazer colocações a qualquer momento. Os brasileiros afirmaram sentir dificuldade em acompanhar essas conversações, geralmente diálogos entre nativos sobre assuntos técnicos, mencionando que "às vezes dá uma travada, dá branco".

A seguir, analisam-se os resultados encontrados para os principais pontos incluídos no roteiro de entrevistas, abordados anteriormente na discussão teórica. 


\section{A quantidade de informação codificada no processo verbal}

Os informantes afirmaram que os americanos tendem a se ater mais aos fatos do que os brasileiros; por isso, fazem muitas reuniões, circulam muitas atas com grande quantidade de informação escrita a respeito do que foi discutido. O número de reuniões é percebido pelos brasileiros como excessivo, algo que toma tempo em demasia e leva a que "sobre pouco tempo para trabalhar".

\section{A maneira de organizar os assuntos no tempo}

Destacou-se a dificuldade que os americanos enfrentam quando os brasileiros resolvem tratar de mais de um assunto ao mesmo tempo ou alterar a ordem de uma agenda de reunião. Os informantes relataram que "os caras ficam loucos" quando não se segue uma ordem linear nas reuniões, saltando pontos da pauta ou retornando a pontos já discutidos. Além disso, embora os superiores sejam acessíveis aos subordinados, estes últimos encontram dificuldade em contatá-los em "função da agenda apertada", pois "são pessoas muito ocupadas", mas, "do momento que se marca hora, eles atendem bem".

Na percepção dos brasileiros, o discurso dos americanos "tem uma forma que vai induzindo passo a passo, são mais factuais do que a gente".

\section{O conteúdo das informações}

De acordo com os entrevistados, os americanos "se resumem ao trabalho", ou seja, restringem-se aos problemas a serem resolvidos, reservam pouco espaço para relacionamentos. Em contraposição, na subsidiária brasileira, "o relacionamento com as pessoas vai além do trabalho".

Todos os informantes confessaram que, para trabalhar bem, precisam conhecer as pessoas, "desenvolver uma camaradagem". Os relacionamentos se estendem para além do ambiente da empresa: "A diversão é sair para almoçar para falar mal dos gringos", "comentar o que aconteceu durante o trabalho". Esta postura, segundo eles, contrasta com a dos americanos, que são mais "profissionais", conseguem trabalhar bem com pessoas "desconhecidas", "terminando a relação quando o expediente acaba". Por exemplo, para os brasileiros, é estranho ir para os Estados Unidos e não ser convidado pelos colegas de trabalho para almoçar ou para algum programa no final de semana.

A necessidade de um bom ambiente de trabalho também se aplica aos clientes e fornecedores. Um dos informantes observou que, tanto na área de vendas como na de manutenção, os relacionamentos são fundamentais para um bom atendimento, pois "se o cara não gosta da pessoa, ele não compra, não conserta, ele diz que está fazendo e não está".

No que se refere à interferência do lado pessoal no trabalho, os informantes acreditam que é mais difícil acontecer nos Estados Unidos do que aqui: "somos mais emotivos". Entretanto, foi ressaltado que, em assuntos graves como câncer na família, por exemplo, pode ser concedida uma licença para o funcionário, o que sugere que o americano prefere afastar-se temporariamente do trabalho a permitir que sua vida pessoal nele interfira.

São feitas observações em relação a reuniões: "nossa forma de reunião é diferente da dos americanos". Assim, para os brasileiros, é necessário um ritual de preparação para se chegar ao assunto principal: cria-se, primeiro, um relacionamento entre as pessoas, depois, então, se inicia o assunto. No "nosso almoço de negócios, a gente trata de negócios na sobremesa, no cafezinho". O importante é que "o relacionamento foi 
criado, porque se tocou no assunto de forma suave". Já os americanos, quando vêm para cá, já "querem falar de trabalho antes do couvert”. Quando não conseguem isso, acham que "perderam o almoço".

\section{O confronto de opiniões}

O diretor acrescentou ainda que "trabalha muito o emocional junto a seus subordinados", procura agir de forma que "seu pessoal trabalhe contente, para ajudar o grupo", pois "esta é uma forma de desenvolver um espírito de equipe, de procurar buscar o melhor para o grupo". No que se refere ao relacionamento entre colegas, observou que o americano tem "uma tendência individualista a querer se sobressair", enquanto "nós temos uma forma mais cooperativa de trabalhar", "as pessoas são aplaudidas quando fazem coisas que vão contribuir para o grupo". Entretanto, ponderou que, na realidade, os dois lados gostam de aparecer: "nós não assumimos esta vontade para não sermos excluídos do grupo". Acrescentou, então, que "aqui a coisa é feita de forma velada; no fundo você quer aparecer, você quer o elogio, mas você não quer que pareça que você está correndo atrás dele"; já nos Estados Unidos, "está todo mundo correndo atrás e a sociedade está aceitando este comportamento".

Durante as visitas, pode-se observar que o escritório visitado apresenta uma estrutura pouco hierarquizada, bastante enxuta, sendo os 21 integrantes atendidos por uma única recepcionista e um office boy. As pessoas servem-se de água e de café, manejam suas agendas e redigem seus textos, dispensando, portanto, a contratação de secretárias.

Para os informantes, os superiores são acessíveis aos subordinados, há em relação a estes uma grande abertura por parte dos chefes. Em comparação aos brasileiros, eles percebem nos americanos "um estilo mais informal, um tratamento mais igualitário, independentemente do nível hierárquico, um ambiente aparentemente mais igual". Segundo os brasileiros, grande parte dos americanos "pratica a política de porta aberta, são muito mais abertos do que a gente".

De acordo com os entrevistados, existe um "código meio informal de que cada um deve dar a sua opinião". A empresa espera que as pessoas intervenham, falem, interrompam. Existe espaço para que as pessoas expressem seus pontos de vista, mesmo que contrários aos da matriz e aos do chefe. As pessoas se "sentem seguras para discordar", percebem que têm poder para tentar mudar as coisas que consideram erradas. Na empresa, "não se encara uma discordância como sinal de desrespeito". Neste aspecto, a principal barreira à comunicação parece ser a língua, não a hierarquia.

Entretanto, durante as entrevistas, transpareceu uma preocupação, por parte dos brasileiros, com a forma de divergir. Os brasileiros afirmaram que procuram "dar uma grande quantidade de argumentos para convencer alguém a aceitar um determinado ponto", ou ainda, "usar uma forma mais branda para dizer as coisas", ao contrário dos americanos que, segundo eles, "tendem a ser mais diretos para dizer as coisas do que nós". Isto se reflete nos textos escritos, nos quais os informantes destacaram a "necessidade de argumentar com elegância, para não ser grosseiro", como o são os americanos em seus e-mails, "especialmente os caras mais técnicos, que escrevem até uma coisa meio grossa: isso não é assim".

No entanto, quando não é possível se chegar a um acordo, os brasileiros, diferentemente dos americanos, evitam "bater de frente". Um dos informantes chegou a afirmar que "a gente tende a concordar para evitar conflito", o que deixa os americanos "doentes", pois depois "não se faz nada do que foi combinado no acordo".

Os informantes destacaram ainda a facilidade que o brasileiro tem de se adaptar "ao que o meio lhe impõe como forma de trabalhar", em contraste com a atitude dos americanos, que "não conseguem se enquadrar em outro meio e tentam impor sua vontade". 


\section{A quantidade de estrutura contida nas informações}

De acordo com o que foi exposto pelo diretor, existe uma postura dos americanos de esperar que o funcionário descubra como o trabalho deve ser feito por si mesmo, "ao invés de o chefe ensinar exatamente o que deve ser feito, aonde podem ser encontradas determinadas informações, etc." Para ele, a empresa define muito bem o que cada um vai fazer, embora a pessoa tenha "liberdade de definir como vai fazer", desde que traga resultado. Os americanos aceitam bem esta política e "procuram descobrir o que devem fazer pesquisando na intranet, por exemplo; eles vão e se viram". O diretor acrescentou que os brasileiros não procuram descobrir, por si mesmos, o que deve ser feito: "se a empresa não ensina, eles ligam para o colega e pedem para o colega ensinar". De acordo com os outros informantes, a não definição por parte dos norteamericanos de como as coisas devem ser feitas é apreciada por alguns brasileiros, que acham interessante desenvolver suas ideias, mas incomoda a outros, que preferem as coisas mais bem definidas. Um dos informantes admitiu sentir-se um pouco dividido com relação a esta questão: ao mesmo tempo que "gostaria de mais esclarecimentos", acha interessante "poder desenvolver algumas ideias". Em contrapartida, os informantes não se mostraram surpresos com a ideia de o chefe mencionar falta de conhecimento sobre algo, tendo um deles comentado que isso teria mudado no Brasil e que também agia desta forma.

\section{A transparência de emoções no discurso}

Na subsidiária brasileira, a demonstração de emoções é vista de forma natural. A ideia de o chefe demonstrar emoção parece ser bem aceita pelo grupo "desde que não haja ofensa a ninguém”. Os informantes foram unânimes em afirmar que não aceitam grosserias, mas que "ser rígido, agir com firmeza, colocar um pouco de emoção" não é algo mal visto, nem considerado ridículo. Dar bronca, bater na mesa não é considerado agressivo. Neste ponto, não parece haver problemas com os americanos, pois "em geral o pessoal que ascende lá fora é de um nível melhor". Um dos informantes chamou atenção para o fato de que "pessoas muito condescendentes não conseguem que as coisas sejam feitas".

No entanto, na percepção dos brasileiros, o discurso que surte efeito com os americanos é aquele bem fundamentado, com argumentos lógicos e não "uma coisa mais emocional".

Evidencia-se a dificuldade dos brasileiros para esconder suas emoções. Nesse sentido, foi destacado que o uso de tecnologia, principalmente a de audioconferências, dificulta a transmissão das emoções, pois exige toda uma adaptação por parte dos brasileiros e, segundo um informante, existe um "protocolo de reunião a ser seguido". Os informantes relatam a necessidade de, por exemplo, "não falar todo mundo ao mesmo tempo, ter que pedir para falar, ter que anunciar quando entra" e a "dificuldade de relaxar" durante as sessões. Entretanto, um dos informantes observou que os clientes preferem, no atendimento, os brasileiros aos americanos, indicando uma superioridade dos primeiros em relação aos últimos nos contatos pessoais.

\section{Análise das entrevistas}

$\mathrm{Na}$ análise do discurso dos informantes, transparece a barreira da língua como a principal dificuldade na comunicação verbal, especialmente no que diz respeito à capacidade de os brasileiros expressarem, com fluência, em inglês, o que estão pensando. Isto vem confirmar as suposições de Sapir-Whorf (apud PORTER e SAMOVAR, 1995), de Hoijer (1994) e Liberman (1994) de que a língua ajuda a moldar padrões de pensamento e a estabelecer categorias significativas.

Os americanos não procuram compreender como os brasileiros funcionam, ignoram seus esforços para acompanhar os conference calls, o que, muitas vezes, os impede de expressar suas opiniões. Nesta atitude 
universalista por parte dos norte-americanos, percebem-se as fontes de falhas na interpretação de significados entre culturas distintas apontadas por Adler (1991): uso de suposições ou normas de uma cultura para compreender outra, falta de conscientização da própria cultura e tendência a ver as outras como mais similares à própria cultura do que realmente são.

\section{A quantidade de informação codificada no processo verbal}

A necessidade de informação codificada no processo verbal parece diferir nas duas culturas. Os informantes sinalizaram que os americanos depreendem menor quantidade de informação do ambiente do que os brasileiros, uma vez que precisam de maior número de reuniões e atas. Estes resultados sugerem que, de acordo com o modelo de Haworth e Savage (1989), os brasileiros são expostos a uma maior quantidade de informação explícita do que desejariam.

\section{A maneira de organizar os assuntos no tempo}

Os depoimentos dos brasileiros indicam que os norte-americanos, da mesma forma que os membros de culturas monocrônicas em relação aos das policrônicas (HALL, 1994b), mostram-se atordoados com o costume dos brasileiros de tratar de várias questões simultaneamente ou de alterar a ordem das agendas de reunião. Ao mesmo tempo, destacam o esforço que precisam fazer para seguir o protocolo monocrônico imposto pelos americanos nas audioconferências. Além disso, os brasileiros percebem que só conseguem contato com os norte-americanos se houver disponibilidade em suas agendas, o que confirma uma maior preocupação das culturas monocrônicas com as tarefas em detrimento das pessoas.

As estruturas de discursos também se mostram consistentes com a forma de os norte-americanos organizarem os eventos no tempo. Na percepção dos brasileiros, os americanos têm uma forma de discurso que vai induzindo passo a passo, sugerindo um discurso linear como o encontrado por Kaplan (apud ULIJN et al., 2000).

\section{O conteúdo das informações}

Na subsidiária brasileira, o processo de comunicação estaria permeado por relações de amizade, uma vez que, ao contrário dos americanos, os brasileiros precisam aprofundar os relacionamentos no grupo para reproduzir, no trabalho, um ambiente familiar, o que estaria de acordo com uma cultura coletivista (HOFSTEDE,1994). Desta forma, os brasileiros não conseguem separar os negócios das relações pessoais, precisam desenvolver relações de confiança ou algum tipo de relacionamento prévio às interações de trabalho.

Os norte-americanos, por sua vez, conseguem trabalhar com pessoas desconhecidas e consideram desnecessário, ou até mesmo perda de tempo, o aprofundamento das relações pessoais nos negócios. Este comportamento dos norte-americanos, de acordo com Trompenaars (1995), seria típico de uma cultura específica e desagradaria aos brasileiros, que apresentariam características de culturas difusas.

\section{O confronto de opiniões}

As entrevistas mostraram a preocupação dos brasileiros em evitar conflitos de ideias para preservar a "harmonia" na escolha por formas de argumentar que não firam suscetibilidades ou, ainda, aceitando 
compromissos com os quais não concordam. Observa-se, portanto, por parte dos brasileiros, uma posição de mediador, conciliador, conforme destacado por DaMatta (2000).

É possível que essa tendência para evitar conflitos esteja por trás do fato de os brasileiros esconderem sua vontade de sobressair para não serem excluídos do grupo, como destacou o diretor. Da mesma forma, quando combinada com uma forte aceitação da hierarquia, a tendência a evitar conflitos talvez explique a facilidade com que os brasileiros acatam a forma de trabalhar dos americanos, evitando bater de frente com os líderes (TANURE, 2005).

Já os norte-americanos expressam livremente seus pontos de vista sem se preocuparem se vão ofender alguém com suas argumentações, o que parece ser decorrente da conjugação de algumas características culturais presentes nessa sociedade, evidenciadas por Hofstede (1994): alto nível de individualismo e pequena distância do poder.

Apesar de não gostarem da forma como os norte-americanos colocam suas opiniões, a baixa distância hierárquica introduzida pelos norte-americanos na subsidiária é bem vista pelos brasileiros, na medida em que favorece um ambiente aberto, em que é permitido ter acesso ao chefe bem como criticá-lo.

\section{A quantidade de estrutura contida nas informações}

A atitude dos norte-americanos em definir o que cada um deve fazer, estabelecendo detalhadamente as funções de cada um, sugere uma posição universalista (TROMPENAARS, 1995) de sua parte. Entretanto, o fato de a matriz estimular que os funcionários descubram onde buscar as informações necessárias e como devem fazer as coisas sinaliza uma menor necessidade de estrutura, consistente com uma maior capacidade de correr riscos e lidar com a incerteza (HOFSTEDE, 1994).

No mesmo sentido, o fato de alguns brasileiros acharem interessante poder desenvolver suas ideias e de não se surpreenderem com o chefe não saber responder a alguma pergunta indica uma menor necessidade de estrutura e sinaliza uma possível queda da fuga à incerteza na cultura brasileira, o que confirmaria os resultados encontrados por Tanure (2005).

Entretanto, é interessante notar que, quando sentem dificuldade, os brasileiros procuram resolver os problemas em relação à ambiguidade recorrendo aos colegas, apelando para o lado relacional, como se espera numa sociedade coletivista. Esta atitude contrasta com a dos norte-americanos que, de forma condizente com uma sociedade individualista, procuram, por si mesmos, descobrir as respostas (HOFSTEDE,1994).

Assim, parece haver indícios de que os americanos, apesar de estabelecerem mais regras e procedimentos, de acordo com sua tendência universalista, não estruturam a forma como as atividades devem ser realizadas, focam nos resultados, o que não parece causar grandes transtornos aos brasileiros.

\section{A transparência de emoções no discurso}

Embora a demonstração de emoções por parte dos norte-americanos seja bem aceita pelos brasileiros, as entrevistas indicam que os norte-americanos preferem um discurso indireto, caracterizado por argumentos lógicos, sem emoção, separando-a das decisões "objetivas" e "racionais", como nas culturas neutras (TROMPENAARS, 1995). 
Já o discurso dos brasileiros parece ser carregado de emoção, como sugere o fato de que, nas audioconferências, precisam moldar seu discurso ao estilo norte-americano, esforçando-se para conter a emoção de modo a não interromper seus interlocutores.

\section{Considerações Finais}

Neste estudo, buscou-se analisar o processo de comunicação dentro da subsidiária brasileira de uma empresa transnacional de origem norte-americana que atua no setor de telecomunicações, de modo a levantar questões importantes na comunicação verbal entre as culturas norte-americana e brasileira, que pudessem resultar em interpretações equivocadas das mensagens enviadas.

Inicialmente cabe destacar a utilidade das dimensões culturais encontradas na literatura como ponto de partida para análises mais profundas, com base no ponto de vista dos informantes. Desta forma, na "visão dos nativos", alguns pontos a respeito dos impactos das diferenças culturais no processo de comunicação na empresa mereceram maior destaque do que outros, indicando que nem todos os aspectos contidos numa mesma dimensão se aplicam da mesma forma a todas as culturas, o que reforça a ideia de que o uso de dimensões pode levar a generalizações excessivas, conforme levantado por Ulijn et al. (2000) e Taras, Rowney e Steel (2009).

Em análise mais específica sobre a interação das duas culturas no processo de comunicação verbal, os informantes enfatizaram como pontos negativos, além da barreira da língua, já mencionada anteriormente, a pouca importância dada pelos americanos às relações pessoais, bem como o discurso adotado pelos americanos, que, muitas vezes, parece "grosseiro" aos olhos dos brasileiros, mais preocupados em manter a harmonia.

Evidenciando a possibilidade de captar sinergias da diversidade cultural, conforme destacado por Boylan (2001), Canclini (2003) e Taras, Rowney e Steel (2009), o "ambiente democrático" proporcionado pelos americanos parece encantar aos brasileiros e estimulá-los a expressar sua opinião. Da mesma forma, o estilo relacional dos brasileiros diante dos clientes vem alcançando bons resultados.

Cabe ressaltar que os fatores que facilitaram a comunicação entre as duas culturas parecem ter sido resultado da interação social entre os participantes, a qual leva ao desenvolvimento de entendimentos compartilhados a respeito de questões de interesse comum, como previsto na análise de Schall (1983). Neste aspecto, destacam-se a existência de uma cultura organizacional forte, deixando claras as regras a serem seguidas, e a flexibilidade com que os brasileiros se adaptam ao estilo de comunicação imposto pelos norte-americanos.

Alguns pontos podem ser indicados como limitações do trabalho. Em primeiro lugar, na escolha das dimensões, podem ter sido ignoradas variáveis importantes na comunicação verbal, por não terem sido abordadas nas dimensões selecionadas ou por não terem sido consideradas relevantes pelo autor. Em segundo lugar, apesar de a opinião dos entrevistados ter convergido na maioria das questões, o número reduzido de entrevistas pode ter influenciado os resultados.

De modo a obter mais subsídios para as questões levantadas neste estudo, recomenda-se que pesquisas futuras não só refinem o modelo utilizado, como investiguem outras subsidiárias brasileiras cujas matrizes estejam localizadas nos Estados Unidos. Também seria relevante replicar o estudo em subsidiárias norteamericanas de empresas brasileiras, de modo a verificar se ocorreriam mudanças em razão de uma inversão nas relações de poder, principalmente no que diz respeito à flexibilidade de adaptação demonstrada pela cultura brasileira. 


\section{Referências}

ADLER, N.J. International dimensions of organizational behaviour. California: Wadworth Publishing Company, 1991.

Spring 1986.

. ; JELINEK, M. Is 'organization culture' culture bound? Human Resource Management, v. 25, n.1, p. 73-90,

BARBOSA, L. O jeitinho brasileiro. 4. ed. Rio de Janeiro: Campus, 1992.

; VELOSO, L. A cultura do outro: interculturalidade e dialogia nas empresas. In: BARBOSA, L. (Coord.). Cultura e diferença nas Organizações: reflexões sobre nós e os outros. São Paulo: Atlas, 2009. p. 161-215.

BARNLUND, D.C. Communication in a Global Village. In: PORTER, R.E.; SAMOVAR, L.A. (Ed.). Intercultural Communication. California: Wadworth Publishing Company, 1994. p. 26-36.

BARTLET, C.A.; GHOSHAL, S. Gerenciando empresas no exterior: a solução transnacional. São Paulo: Makron Books do Brasil, 1992.

BEAMER, L. A schemata model for intercultural encounters and case study: the emperor and the envoy. The Journal of Business Communication, v. 32, n. 2, p. 141-161, 1995.

BOYLAN, P. To be or not to be: success or failure in intercultural communication. Disponível em: <http://www.uniroma3.it/ling/boylan>. Acesso em: jun. 2001.

CANCLINI, N.G. A Globalização imaginada. Tradução Sérgio Molina. São Paulo: Editora Iluminuras, 2003.

DAMATTA, R. A casa \& a rua: espaço, cidadania, mulher e morte no Brasil. 6. ed. Rio de Janeiro: Rocco, 2000.

D'IRIBARNE, P. Conceituando culturas nacionais: uma abordagem antropológica. In: BARBOSA, L. (Coord.) Cultura e diferença nas organizações: reflexões sobre nós e os outros. São Paulo: Atlas, 2009. p. 17-29.

FOURBOUL, C.V.; BOURNOIS, F. Strategic communication with employees in large European companies: a typology. European Management Journal, v. 17, n. 2, p. 204-217, 1999.

FREITAS, A.B. Traços Brasileiros para uma análise organizacional. In: MOTTA, F.C.P.; CALDAS, M.P. (Org.). Cultura organizacional e cultura brasileira. São Paulo: Atlas, 1997. p. 38-54.

HALL, E.T. The dance of life: the other dimension of time. New York: Anchor Press/Doubleday, 1984.

Context and Meaning. In: PORTER, R.E.; SAMOVAR, L.A. (Ed.). Intercultural Communication. California: Wadworth Publishing Company, 1994a. p. 60-70.

Monochronic and polychronic time. In: PORTER, R.E; SAMOVAR, L.A. (Ed). I Intercultural Communication. California: Wadworth Publishing Company, 1994b. p. 264-271.

HAMPDEN-TURNER, C.; TROMPENAARS, F. The seven cultures of capitalism. London: Piatkus, 1995.

HAWORTH, D.A.; SAVAGE, G.T. A channel-ratio of intercultural communication: the trains won't sell, fix them please. The Journal of Business Communication, v. 26, n. 3, p. 231-254, 1989.

HILAL, A.; HOFSTEDE, G. Organizational culture dimensions: findings from a brazilian company. In: WORKSHOP EM INTERACIONALIZAÇÃO DE EMPRESAS, 4., 2003, Rio de Janeiro. Anais... Rio de Janeiro: COPPEAD, 2003. 1 CD-ROM. 
HOFSTEDE, G. Culture's consequences: international differences in work-related values. Beverly Hills: Sage Publications, 1980.

Cultures and organizations: the software of the mind. London: McGraw Hill, 1994.

HOIJER, H. The Sapir Hypothesis. In: PORTER, R.E; SAMOVAR, L.A. (Ed.). Intercultural Communication. California: Wadworth Publishing Company, 1994.p. 194-201.

LEWIS, R.D. When cultures collide. London: Nicholas Brealey Publishing, 1996.

LIBERMAN, D.A. Ethnocognitivism, Problem Solving and Hesmispherecity. In: PORTER, R.E.; SAMOVAR, L.A. (Ed.). Intercultural Communication. California: Wadworth Publishing Company, 1994. p.178-193.

MOTTA, F. C. P. Cultura e organizações no Brasil. In: MOTTA, F.C.P.; CALDAS, M.P. (Org.). Cultura organizacional e cultura brasileira. São Paulo: Atlas, 1997. p. 25-37.

PORTER, R.E. An introduction to intercultural communication. In: PORTER, R.E.; SAMOVAR, L.A. (Ed.). Intercultural Communication. California: Wadworth Publishing Company, 1994. p. 04-26. . ; SAMOVAR, L.A. Communication Between Cultures. California: Wadworth Publishing Company, 1995.

PRATES, M.A.; BARROS, B.T. O estilo brasileiro de administrar: sumário de um modelo de ação cultural brasileiro com base na gestão empresarial. In: MOTTA, F.C.P.; CALDAS, M.P. (Org.). Cultura organizacional e cultura brasileira. São Paulo: Atlas, 1997. p. 55-69.

ROCHA, E. O que é etnocentrismo? São Paulo: Brasiliense, 1994.

SCHALL, M.S. A communication-rules approach to organizational culture. Administrative Science Quarterly, v. 28, p. 557-581, Dec. 1983.

SOBRAL, F.; CARVALHAL, E.; ALMEIDA, F. O estilo brasileiro de negociar. Revista Portuguesa e Brasileira de Gestão, p. 35-42, abr./jun. 2007.

TANURE, B. Gestão à brasileira: uma comparação entre América Latina, Estados Unidos, Europa e Ásia. 2. ed. São Paulo: Atlas, 2005.

TARAS, V.; ROWNEY, J.; STEEL, P. Half a century of measuring culture: Review of approaches, challenges, and limitations based on the analysis of 121 instruments for quantifying culture. Journal of International Management, v. 15, p. 357-373, 2009.

TROMPENAARS, F. Riding the waves of culture: understanding culture diversity in business. London: Nicholas Brealey Publishing, 1995.

ULIJN, J. et al. Innovation, corporate strategy, and culture context: what is the mission for international business communication? The Journal of Business Communication, v. 37, n. 3, p. 293-316, 2000.

VARNER, I. I. The theoretical foundation for intercultural business communication: a conceptual model. The Journal of Business Communication, v. 27, n. 1, p. 39-57, 2000.

YEGANEH, H. The "Great Satan" talks with the "Evil": a cross cultural analysis of the American-Iranian communication/negotiation styles. International Journal of Conflict Management, v. 22, n. 3, p. $219-238,2011$. 